\title{
A leitura literária e a ENCENAÇÃo dOS \\ PARADOXOS DA LINGUAGEM
}

http://dx.doi.org/10.1590/1984-0292/1316

\section{Leonardo Pinto de Almeida $\star$}

Universidade Federal Fluminense, Campos dos Goytacazes, RJ, Brasil

\begin{abstract}
RESUMO
O presente artigo tem como objetivo analisar os paradoxos deflagrados na leitura literária. Mostramos que o paradoxo aponta para a dissolução das identidades fixas e do sentido único. Partindo da concepção da literatura como escrita transgressiva, procuramos compreender a dinâmica relativa à leitura literária à luz da noção de paradoxo. Concluirmos à luz do entendimento da leitura literária como cena paradoxal, que em sua experiência não há um sentido único, comportando inúmeras exegeses, nem identidades fixas, pois assinala para a evanescência do leitor, a morte do autor e o desmantelamento da obra.

Palavras-chave: experiência literária; leitura; linguagem.

\section{The literary ReAding AND THE Staging OF THE PARADOXES OF LANGUAGE}

\begin{abstract}
This article aims to analyze the paradoxes triggered in literary reading. We show that the paradox points to the dissolution of the fixed identities and the unique sense. From the conception of literature as transgressive writing, we understand the dynamics on the literary reading in the light of the notion of paradox. Conclude in the light of understanding of reading literary scene as paradoxical, that in his experience there isn't a single direction, comprising numerous exegeses, or fixed identities, because it points to the evanescence of the reader, the author's death and the dismantling of the work.
\end{abstract}

Keywords: literary experience; reading; language.

\footnotetext{
^Endereço para correspondência: Universidade Federal Fluminense, Instituto de Ciências da Sociedade e Desenvolvimento Regional. Rua José do Patrocínio, 71 - Centro. 28015-385 Campos dos Goytacazes, RJ - Brasil. E-mail: leonardo.p.almeida@gmail.com
} 
A imagem criada por Sartre (1947), Situations I, sobre a leitura de um romance ser como um salto em um espelho representa com vigor aquilo que podemos chamar de cena paradoxal do campo experiencial do ler. Ler literatura é como ser jogado em uma zona em que forças reativas e ativas atuam ao mesmo tempo.

Em Lógica do sentido, Deleuze (2000) aponta, ao analisar alguns traços do pensamento dos estóicos e algumas imagens evocadas pela Alice de Carroll (2001), que os paradoxos se caracterizam pela destruição do sentido único e das identidades fixas.

Da mesma forma, o paradoxo é a subversão simultânea do bom senso e do senso comum: ele aparece de um lado como os dois sentidos ao mesmo tempo do devir-louco, imprevisível; de outro lado, com o não-senso da identidade perdida, irreconhecível. Alice é aquela que vai sempre nos dois sentidos ao mesmo tempo: o país das maravilhas tem uma dupla direção sempre subdividida. Ela é também aquela que perde a identidade, a sua, a das coisas e a do mundo (DELEUZE, 2000, p. 81).

Como o "País das Maravilhas", o espaço literário se caracteriza por habitar alguns paradoxos imanentes à linguagem. O principal seria a condição da linguagem de estar entre a transgressão e os limites. Ela transgride os próprios limites que a constituem. Este fato seria justamente o que proporcionou o surgimento de uma escrita, nos Tempos Modernos, que afirmava inelutavelmente sua posição contrária às religiões e às tradições vigentes. Esta forma de escrita foi chamada por Foucault (2001a), em "Prefácio à transgressão", de literatura.

A literatura seria dificilmente capturada em um sentido único, por contracenar, através de seus personagens, hipóteses até contraditórias entre si. A literatura se caracterizaria por ser aberta, já que a obra não teria um sentido somente, mas muitas exegeses, fugindo assim a qualquer ideia de tradição.

Outro ponto considerado por Foucault (2001b), em “O que é um autor?”, seria a dissolução existencial do escritor na atividade de escrever. Sua identidade é desfocada pelo nascimento da obra, sobrando somente seu nome para alicerçar a trama dos discursos. O nome do autor seria aquele que amarra os discursos entre si. Sua função seria a de doar ordem à proliferação linguageira. Daí, podermos apontar uma diferença entre a figura do escritor, sendo àquele que desaparece na experiência total do escrever, e o autor, sendo o nome que permanece colocado à obra para ordenar os discursos.

No entanto, o problema não se resumiria simplesmente a isso, devido ao fato de que a experiência literária não se reduz tão-somente à escrita. A leitura surge como uma atividade tão cara à experiência literária quanto à escrita. Escrita e leitura se complementam e andam juntas no espaço literário. 
Salientemos que, tanto Foucault (2001b), ao analisar "o desaparecimento do escritor ou do autor", quanto Barthes (1984), em "A morte do autor", não diferenciam o escritor do autor. Sendo que, em Barthes, "a morte do autor" soa ora como a dissolução existencial do escritor na experiência total do escrever, ora como a morte do autor como referência.

Podemos pensar também que o texto barthesiano marca uma posição de crítica em relação às "palavras de poder", representadas pelas figuras do autor, da obra e da crítica. Ele afirma que o reinado da autoria estaria intrinsecamente ligado ao reinado do editor e à manutenção feita pela ordenação do universo escrito pela figura do crítico. Crítico, Editor e Autor seriam os representantes ilustres do domínio sobre o saber escrito.

Dar ao texto um Autor é impor-lhe um travão, é provê-lo de um significado último, é fechar a escritura. Essa concepção convém muito à crítica, que quer dar-se então como tarefa importante descobrir o Autor (ou as suas hipóteses: a sociedade, a história, a psique, a liberdade) sob a obra: encontrado o Autor, o texto está 'explicado', o crítico venceu; não é de se admirar, portanto, que, historicamente, o reinado do Autor tenha sido também o do Crítico, nem tampouco que a crítica (mesmo a nova) esteja hoje abalada ao mesmo tempo que o Autor (BARTHES, 1984, p. 69).

Neste trecho, vemos bem como se relaciona, segundo Barthes, a autoria como mecanismo de ordenação dos livros e dos discursos - e a crítica literária francesa, criticada por ele neste texto, que remonta à invenção do método de Sainte-Beuve e suas reverberações ao longo da teoria da literatura na França, como no caso da crítica lansoniana. ${ }^{1}$

No entanto, podemos apontar um certo panfletarismo nas afirmações de Barthes em relação à suposta morte da figura do Autor como referência. Couturier (1995) coloca em pauta, de forma sucinta, este aspecto da crítica barthesiana, ao sustentar que a crítica francesa da época deste texto de Barthes era ainda fundada em uma perspectiva que afirmava estar a verdade da obra relacionada com a vida do escritor. E mostra ainda que a crítica anglo-saxônica não procedia da mesma maneira:

É muito fácil hoje estigmatizarmos o exagero desta proposta. Esquece-se que a crítica francesa dos anos sessenta era essencialmente lansoniana e teria tomado, a maior parte do tempo, suas interpretações do texto literário do autor, como testemunha os títulos de muitas teses da época: ' $\mathrm{X}$, o homem e a obra'. Este texto de Barthes seria um manifesto, ou seja, um ato militante que visava destronar o deus que a crítica adorou por mais de um século. A crítica francesa sustentava $o$ autor como garantia do sentido. A crítica inglesa e americana não compreendia a veemência destas propostas, já que ela seria bizarramente mais formalista do que a nossa, desde 
notadamente T. E. Hulme et I. A. Richards, substituídos do outro lado do Atlântico pela Nova Crítica de John Crowe Ransom, Allen Tate, R. P. Blackmur, Clean Brooks ou W. K. Wimsatt (COUTURIER, 1995, p. 12-13).

Poderíamos, assim, apontar este caráter exagerado do manifesto de Barthes em sua tentativa de dar ao leitor um lugar privilegiado no universo dos livros. Ele afirma, neste texto, que "o nascimento do leitor deve pagar-se com a morte do Autor” (BARTHES, 1984, p. 70). Esta afirmação indica uma forte crítica à referência à figura do autor e ao desleixo em relação ao leitor por parte dos estudos literários franceses. Contudo, ao entender a morte do Autor como o desaparecimento do Autor como referência na trama dos discursos, Barthes, como Couturier (1995) mesmo afirma ao longo de seu texto, dá abertura para inúmeras imposturas intelectuais de seu tempo.

Quando lemos agora 'A morte do Autor', temos, como efeito, a impressão de que Barthes legitima antecipadamente algumas imposturas, mesmo se ele deu provas de menos arrogância do que alguns de seus discípulos (COUTURIER, 1995, p. 10).

No entanto, estas imposturas não são objetos de nossa análise. ${ }^{2} \mathrm{O}$ que queremos mostrar, com isso, é a confusão barthesiana entre as duas figuras: autor e escritor para avançar nossa compreensão sobre a leitura literária e suas relações com essas figuras. A escrita moderna não demarca uma experiência em que o autor desaparece. Quem desaparece no caso da escrita literária é o escritor, como sujeito cuja existencialidade é dissolvida ao longo da experiência total do escrever.

Todavia, uma coisa importante surge: as preocupações críticas em relação à posição do leitor, frente ao objeto literário, não apontam para a morte do Autor como referência, pois a referência ao Autor está longe de ser destruída. Contudo a experiência leitora é aquela que está em constante luta com as ideias fechadas de obra e de autor. A experiência leitora, em sua atitude diletante, marca um posicionamento que não leva em conta as origens do texto. Daí, sua constante luta com a figura do autor. Pois não é a crítica literária que se debruça sobre as vicissitudes da leitura que assinala a morte do Autor como referência na trama discursiva, e sim a experiência total do ler é que seria precisamente aquela que faz desaparecer a questão da origem, ou seja, a autoria como referência, e mesmo a angústia e o trabalho árduo do escritor em seu processo de desaparecimento. Sobre esse ponto, Blanchot (1997, p. 193) sublinha que

[...] toda a infinita ligeireza do leitor afirma a nova ligeireza do livro, convertido em livro sem autor, sem a seriedade, o trabalho, as pesadas angústias, o peso de toda uma vida que nele se verteu, experiência por vezes terrível, sempre temida, que o leitor apaga e, em sua ligeireza providencial, considera como nada. 
Foucault (1999), ao homenagear Blanchot, afirma que a literatura seria, evidentemente, "a parte do fogo", pois nela tudo é dissolvido, consumido, desaparecido. Estranho movimento de aparecimento-desaparecimento das coisas, das palavras, do mundo e do homem. Com isso, poderíamos acrescentar que, na experiência literária, a escrita assinala o desaparecimento existencial do escritor, enquanto a leitura indicia a morte do autor, ou o desligamento experiencial em relação à origem do texto.

E como podemos entender este movimento de desaparecimento do autor quando a obra atravessa o campo experiencial do ler? Em um texto posterior ao artigo supracitado, “A morte do autor", escrito em 1968, Barthes (2002) analisou algumas questões importantes relativas à apreensão do objeto literário. Neste escrito, ele tenta construir um entendimento da leitura calcada nos conceitos de prazer e fruição do texto.

Texto de prazer: aquele que contenta, enche, dá euforia; aquele que vem da cultura, não rompe com ela, está ligado a uma prática confortável da leitura. Texto de fruição: aquele que põe em estado de perda, aquele que desconforta (talvez até um certo enfado), faz vacilar as bases históricas, culturais, psicológicas do leitor, a consistência de seus gostos, de seus valores e de suas lembranças, faz entrar em crise sua relação com a linguagem (BARTHES, 2002, p. 20-21).

Ao longo deste livro, esta diferenciação entre textos de prazer e textos de fruição parece sofrer da mesma arbitrariedade denominativa de que ele acusa a crítica literária de seu tempo. Como podemos afirmar que um texto seria de prazer e o outro de fruição? Estas qualidades não estariam no texto em si, mas na relação que o sujeito e a obra são convidados a estabelecer junto ao campo experiencial do ler.

Aqui, gostaríamos de chamar a atenção para esta questão do prazer. Realmente, o prazer remete a uma posição mais confortável, não somente porque ela pode ou não afirmar a cultura, mas porque a ideia de prazer remete a um Eu que permanece. Contudo, a ideia de prazer nos servirá aqui para entendermos por que o autor, como remetimento à origem do texto, morre ou desaparece no momento da leitura literária.

O prazer tem como característica principal o apagamento da questão relativa à sua gênese. Quando fumamos um cigarro, por exemplo, não nos perguntamos sobre a procedência do tabaco. O prazer proporcionado pelo cigarro e a experiência de fumá-lo tem seu fim nela mesma. Não me importa a procedência do tabaco nem que este prazer possa me custar um problema de saúde futuro. Ou, ainda, quando beijamos alguém que nos fascina, este beijo apaga todos os beijos dados até então. Só existe este beijo na experiência de beijar. Os beijos passados e futuros são frutos de indagações feitas quando não há mais o beijo. Durante a experiência 
de beijá-la, não nos perguntamos se ela tem boa família, educação, nem se teve muitos namorados, nem se eu serei seu novo companheiro. $\mathrm{O}$ beijo tem seu fim nele mesmo, por apagar o passado e o futuro no turbilhão da experiência.

Podemos fazer um paralelo com a leitura literária, pois uma de suas características principais é que ela apaga a figura autoral. A leitura literária tem como fim ela mesma. Não me importa quem escreveu enquanto estou lendo, somente antes ou depois da obra lida, ou melhor, quando não a estou lendo.

Em $O$ espaço literário, Blanchot (1987) afirma que a leitura literária se apresenta como um embate entre o leitor e o autor, pois ler literatura é negar, de certa forma, a própria existência do autor. A leitura literária se quer mais livre, pois "o leitor não se acrescenta ao livro, mas tende, em primeiro lugar, a aliviá-lo de todo e qualquer autor" (BLANCHOT, 1987, p. 193). Desta maneira, poderíamos assinalar que a verdadeira "morte do autor" é aquela produzida pela leitura literária.

No entanto, gostaríamos de reafirmar que a noção de prazer não constitui a experiência total do ler em seu todo. Por este motivo, utilizemos a noção de efusão do ler, pois ela aponta para os paradoxos da leitura. Efusão, propagação, ressonância são características imanentes ao campo experiencial do ler. Ler literatura é ser jogado em uma cena paradoxal em que há a dissolução da origem do texto (a morte do autor), o desmoronamento da obra (o désœuvrement é o movimento que torna a obra - este conceito fechado da criação literária - um livro) e o desaparecimento do eu que lê.

Neste ponto, e parafraseando uma sentença blanchotiana contida em A parte do fogo (1997), ressaltamos que o leitor que lê uma obra literária se suprime na leitura ao mesmo tempo em que se afirma. Contudo, esta questão se encontra desenvolvida, em $O$ espaço literário, quando Blanchot (1987) sublinha que o processo de leitura não só apaga a autoria como também não leva em conta o leitor, como sujeito provido de uma existencialidade. A "ligeireza" da leitura literária é a própria afirmação da obra. No entanto, esta característica não seria nem um diálogo entre autor e leitor, nem uma submissão do leitor frente à intenção do autor, nem uma reação projetiva dos desejos do leitor sobre o texto literário. $\mathrm{O}$ leitor se afirma em seu acolhimento da obra e se perde na sedução da obra.

A leitura que toma a obra pelo que ela é e, assim, a desembaraça de todo o autor, não consiste em introduzir, no lugar dele, um leitor, uma pessoa fortemente existente, possuidora de uma história, uma profissão, uma religião e até de leitura, que, a partir de tudo isso, começaria, com a outra pessoa que escreveu o livro, um diálogo. A leitura não é uma conversação, ela não discute, não interroga. Jamais pergunta ao livro e, com mais fortes razões, ao autor: $<0$ que foi que você quis dizer exatamente? Que verdade me traz, portanto?> A leitura verdadeira jamais questiona o livro verdadeiro; mas tampouco é submissão ao <texto> (BLANCHOT, 1987, p. 194). 
Para entendermos este problema relativo ao apagamento do autor e do leitor na experiência literária, podemos nos valer de um exemplo. Ao ler um conto de Maupassant (2000), chamado "Apparition", somos convidados a submergir numa história de medo, mistério e angústia.

Em uma reunião íntima em um antigo hotel de Paris, o Marquês de la TourSamuel, já com seus 90 anos, conta um episódio ocorrido há 53 anos, cuja marca de medo, impressa sobre seu corpo, perdurou ao longo de sua existência.

Era julho de 1827 e, nas mediações da cidade de Rouen, onde morava, o marquês encontrou um velho amigo de infância e este lhe narrou os infortúnios que assolavam sua vida. Apaixonara-se ardorosamente por uma mulher, com quem se casou e viveu uma feliz relação; até que, devido a uma doença do coração, ela morreu.

A morte da esposa cobria o homem de uma penúria tal que ele se dizia impossibilitado de voltar à casa onde havia passado tantos momentos felizes. Por isso, ele pede para o Marquês buscar, em sua moradia, documentos importantes de que necessitava.

O Marquês vai à casa, como lhe fora solicitado. Ao procurar os documentos na escrivaninha (em meio à escuridão, já que não conseguiu abrir a janela), sente atrás de si um barulho que lhe causa uma sensação desagradável. Ao se virar com receio, avista uma mulher de branco o observando.

Com muito medo, o marquês espera que a aparição se manifeste e ela efetivamente o faz, dizendo: "Você pode me salvar, me curar. Eu sofro terrivelmente. Eu sofro, oh! Eu sofro!" (MAUPASSANT, 2000, p. 95) O Marquês, paralisado, responde que pode ajudá-la e então ela murmura: "Penteie-me, oh! Penteie-me, isto me curará; é necessário que me penteie. Olhe minha cabeça [...] como sofro; e meus cabelos, como eles me fazem mal!" (MAUPASSANT, 2000, p. 95) E, após penteá-la, o Marquês foge para sua casa, constatando não ter sofrido uma alucinação, já que sobre sua roupa ainda restavam fios dos cabelos da mulher.

Segundo o Marquês, ele enviou a seu amigo, por um empregado, os documentos requeridos. E, no dia seguinte, tentou contatá-lo para contar toda a história, mas jamais o reencontrou e nunca soube como explicar a alguém a situação vivida naquele dia.

Em quê este conto de Maupassant poderia nos ajudar no entendimento do que ocorre no campo experiencial do ler? No encontro com esta história, o leitor, mesmo sabendo de antemão informações sobre o autor, o processo de criação deste conto, o gênero literário em que ele é encerrado, entre outras coisas, ele o sabe para assim esquecer. Pois em quê estas informações nos ajudariam no entendimento do que acontece com o Marquês de la Tour-Samuel?

$\mathrm{Na}$ experiência de ler este conto, estamos em constante luta com o autor e estas informações externas à obra. Afinal de contas, no espaço de ressonância, Maupassant passa a ser apenas um nome que resta impresso sobre a capa de um livro, pois ele é esquecido no decorrer da experiência. O que importa é o que a 
história suscita no corpo do leitor. Quando o sujeito que lê sente os calafrios, as angústias, as emoções sem explicação que atravessam o personagem ao avistar perto de si a mulher vestida de branco, não existe na experiência nada além desta cena vivenciada na leitura. Quem, como e quando escreveu não tem importância alguma enquanto o leitor estiver no turbilhão da experiência.

Em O espaço literário, Blanchot (1987, p. 193) mostra de forma clara esta característica da leitura e seu embate com a figura autoral:

Sem que o saiba, o leitor está empenhado numa luta profunda com o autor: seja qual for a intimidade que subsiste hoje entre o livro e o escritor, por mais diretamente que sejam esclarecidas pelas circunstâncias da difusão, a figura, a presença, a história de seu autor - circunstâncias que não são fortuitas mas talvez já ligeiramente anacrônicas - apesar de tudo isso, toda a leitura em que a consideração do escritor parece desempenhar um papel tão grande implica num ataque contra ele que o anula para entregar a obra a si mesma, à sua presença anônima, à afirmação violenta, impessoal, que ela é. O próprio leitor é sempre profundamente anônimo, é, não importa que leitor, único mas transparente.

Os esclarecimentos sobre a obra entram em estado de perda de si no movimento da experiência. É curioso como a sedução do acolhimento da obra em relação ao leitor o leva a acolhê-la como uma afirmação violenta, impessoal, ou seja, sem autor, mas também sem leitor. Blanchot (1987, p. 194) afirma que "o livro tem, de certo modo, necessidade do leitor para tornar-se estátua, necessidade do leitor para afirmar-se coisa sem autor, e também sem leitor”. A obra literária necessita do leitor para se tornar o que é. Ela precisa dele para sair do estado inerte de obra - que contém letras mortas -, para finalmente se tornar o espaço de ressonância onde passa a ser um livro sem origem e sem dono.

Deste modo, o espaço literário e a afirmação da obra na experiência literária apontam para a evanescência de identidades fixas: escritor, autor e leitor; e para o caráter fugidio do objeto literário - as questões do sentido da obra.

O espaço literário é como o país das maravilhas, pois nele não há um sentido único nem identidades realmente fixas. Há identidades, mas são identidades evanescentes. Há sentido, porém não um único sentido. Podemos vislumbrar, no espaço literário, várias exegeses possíveis, dissoluções dos eus cotidianos do escritor e do leitor, apagamento do autor e desmoronamento da obra. Tudo isso ocorre num campo experiencial em que se vislumbra a questão da superfície e aponta para aquilo que Sartre (1947) chamou de "o horizonte movente do objeto literário".

O paradoxo aparece como destituição da profundidade, exibição dos acontecimentos na superfície, desdobramento da linguagem, ao longo deste limite. O humor é esta arte da superfície, contra a velha ironia, arte das profundidades ou das alturas (DELEUZE, 2000, p. 9-10).

Fractal, Rev. Psicol., v. 26 - n. esp., p. 729-746, 2014 
Deleuze (2000), em uma nota de rodapé contida neste mesmo livro, intitulado Lógica do sentido, ressalva que esta questão da superfície atravessa a literatura moderna. No trecho citado, ao lembrarmos da reflexão de Kundera sobre a arte do romance, podemos aproximar realmente as características da literatura moderna, apontada pelo autor tcheco, à questão da superfície assinalada por Deleuze.

Kundera (1993), em Les testaments trahis, contrapõe a arte do romance e seu caráter humorístico à seriedade dos pensamentos filosóficos, metafísicos e científicos. O humor seria a arte do romance e, por conseguinte, a arte da superfície. A experiência literária é uma experiência da superfície. É como se ela estivesse na fronteira, entre o passado e o futuro por vir. Entre a memória, a intencionalidade do texto e o livro por vir. Porém, a experiência literária encena um paradoxo: não seria bem um estar entre, mas um estar ao mesmo tempo, no passado das memórias subjetivas e textuais e no futuro dos sentidos e das ressonâncias subjetivas. Ela é uma experiência de superfície, pois o paradoxo que ela encena anula o caráter profundo do passado e do futuro. Não há nada além dos elementos subjetivos e de sentido que entram no campo ressonante.

A experiência literária seria, então, uma experiência de superfície, do humorístico, do paradoxo, do questionamento e da perda de si, do desmoronamento da linguagem e da própria noção de obra. Poderíamos, assim, contrapô-la aos movimentos de sistematização crítica e de unificação e enquadramento cultural das obras literárias que representam pesquisas de profundidade. ${ }^{3}$

A obra, o escritor, o autor e o leitor perdem seu nome, sua identidade no turbilhão da experiência. Para visualizarmos esta característica do espaço literário, podemos observar o que acontece com Alice quando ela se encontra no país das maravilhas.

A lagarta e Alice olharam-se por algum tempo em silêncio. Por fim, a Lagarta tirou o narguillé da boca e dirigiu-se a Alice com uma voz lânguida e sonolenta.

'Quem é você?' disse a Lagarta.

Não era um começo de conversa muito estimulante. Alice respondeu um pouco tímida: 'Eu... eu... no momento não sei, minha senhora... pelo menos sei quem eu era quando me levantei hoje de manhã, mas acho que devo ter mudado várias vezes desde então.' (CARROLL, 2001, p. 60)

Como o leitor, Alice encontra-se diferente muitas vezes ao longo de sua experiência. Na medida em que a experiência avança, o espaço de ressonância produz mudanças tanto subjetivas quanto de sentido.

Nota-se, portanto, que no campo experiencial do ler encontramos elementos que compõem pelo menos duas esferas imanentes à leitura: uma, que seria a esfera subjetiva; outra, a esfera de sentido. 
Em relação à primeira, salientemos que, ao mergulhar na experiência, o sujeito possui características como: sua história, sua classe social e econômica, sua capacidade intelectual, sua relação com as línguas maternas e estrangeiras, sua gama de leituras anteriores, suas características personalísticas, sua memória erudita e emocional, assim por diante. Todas estas características compõem a possível esfera de sentido da experiência. Elas podem jogar ou não este jogo estranho que é o jogo da linguagem.

A relação estabelecida, neste espaço de ressonância, pode ser entendida se observarmos como metáfora desta, por exemplo, as relações amorosas. João teve dois relacionamentos marcadamente diferentes com suas últimas duas namoradas. Com a primeira, Melissa, João teve um relacionamento conturbado pelos ciúmes que sentia. Ele era apaixonado, mas Melissa não lhe inspirava confiança, o que fazia João por vezes sair de si. Com a segunda, Alessandra, uma mulher decidida e independente, João teve um relacionamento de carinho, compreensão, e os dois nunca se desentenderam. Agora, em quê esta breve história pode nos ajudar a compreender a dinâmica da esfera subjetiva?

O sujeito é a intersecção de muitas características sociais, comportamentais e mentais, sendo que estas se manifestam caso sejam evocadas pelo contato com o mundo, e passam tão-somente a existir quando manifestadas. Um observador desatento poderia pensar que João é um sujeito estressado, ciumento e violento, devido a seu comportamento com Melissa. No entanto, um outro, ao observá-lo perto de Alessandra, poderá intuir que João é um homem calmo e decidido. O que estas observações assinalam? Elas marcam posicionamentos reflexivos tomados do exterior da experiência, determinando características profundas do sujeito observado.

Contudo, se voltarmos os olhos para a pequena história, podemos observar que João não é estressado, ciumento, violento, calmo ou decidido, mas que a experiência com estas diferentes mulheres convocou elementos da esfera subjetiva que o fizeram manifestar um determinado comportamento. Na leitura literária, a esfera subjetiva se quer imanente à experiência, por ser convocada pela leitura e só existir como manifesto derivado da ressonância.

Em se tratando da esfera do sentido, podemos sublinhar o mesmo que afirmamos sobre a esfera subjetiva. As características textuais, história, autor, ou melhor, as intenções do texto só existem quando manifestadas no campo experiencial do ler. Não esqueçamos que, sem a leitura, a obra é apenas um conjunto de letras mortas. Mais ainda, que as informações sobre o texto são esquecidas no movimento da leitura para assim se dar o acolhimento e o entendimento ${ }^{4}$ do sentido da obra.

O embate destas duas esferas demonstra os paradoxos da leitura literária: liberdade e automatismo, intencionalidade do texto e afirmação leitora. Podemos visualizar este problema da seguinte maneira: o leitor, quando atravessa o espaço literário, acolhe e é acolhido pela obra. A natureza deste acolhimento incide em 
uma postura curiosa sobre o universo da linguagem, em se tratando da relação do leitor com a intencionalidade do texto: sua atitude afirmativa está entre a postura louca de Humpty Dumpty e a de um subordinado à intenção do texto.

Este personagem da novela de Carroll (2002), intitulada "Através do espelho e o que Alice encontrou por lá", apresenta, em sua conversa com Alice, uma atitude que não leva em conta o peso das palavras, afirmando com convicção que se deve ter o domínio sobre elas. Observemos o diálogo entre Alice e este personagem da obra de Carroll.

$<$ Mas 'glória' não significa 'um belo e demolidor argumento', Alice objetou.>

$<$ Quando eu uso uma palavra, disse Humpty Dumpty num tom bastante desdenhoso, ela significa exatamente o que quero que signifique: nem mais nem menos.>

$<$ A questão é, disse Alice, se pode fazer as palavras significarem tantas coisas diferentes.>

$<$ A questão, disse Humpty Dumpty, é saber quem vai mandar - só isto> (CARROLL, 2002, p. 204).

A cena paradoxal da leitura literária poderia ser representada por este diálogo: o leitor encena uma atitude de respeito às palavras, querendo fazê-las significarem o que elas designam (a defesa de Alice do significado das palavras) e, ao mesmo tempo, se mostra rebelde ao cindi-las para fazer significar o que seus componentes subjetivos proclamam (atitude de Humpty Dumpty). Desta maneira, podemos ressaltar que a postura da leitura literária se relaciona com aquilo que é designado pelo tracejar da leitura singular e com o programa de leitura intentado pelo texto, simultaneamente. Este paradoxo seria evidentemente o sentido próprio da liberdade leitora. Não ser louco como um Humpty Dumpty nem uma ovelha que segue o pastor do sentido, representado pela imagem teórica que temos da intenção do texto. Ou ainda, ser os dois ao mesmo tempo.

Em Contre Sainte-Beuve, Proust (1954), ao examinar a questão relativa à leitura, salienta que a linguagem literária possibilita este contato paradoxal de usos do sentido, em que há um programa textual para a leitura, mas a leitura se apropria desta programação muitas vezes, através de um contra-senso. PiegayGros (2002) afirma que isso se dá, evidentemente, porque o programa do texto literário é aberto, por não dizer tudo o que deveria supostamente dizer. O livro literário é aberto porque suscita que a liberdade floresça. Sobre essa questão, Proust (1954, p. 297-298) expõe que:

Os grandes livros são escritos em uma espécie de língua estrangeira. Sob cada palavra, cada um coloca seu sentido ou ao menos sua imagem que é com freqüência um contrasenso. Mas nos grandes livros, todos os contra-sensos que fazemos são belos. Quando li 'Le Berger de l'Ensorcelée', 
eu vi um homem à Mantegna, e a cor da T... de Boticelli. Isto talvez não seja de maneira alguma aquilo que tinha visto Barbey. Mas existe na descrição um conjunto de relações que tendo dado o ponto de partida falso de meu contra-senso, deu-lhe a mesma progressão de beleza.

O espaço de ressonância leitora sublinha um campo imanente. Quando este campo sofre um processo de dialetização, há uma separação dos elementos das esferas de sentido e subjetiva, com o intuito de responder às pesquisas da profundidade. É curioso como apreensões dialetizantes da experiência visam sobrepor os paradoxos com as noções de contradição e de erro. Deleuze (2000, p. 77) afirma que "a força dos paradoxos reside em que eles não são contraditórios, mas nos fazem assistir à gênese da contradição".

Além destas dissoluções das identidades fixas do autor e do leitor e destes problemas relativos ao sentido das palavras, não podemos deixar de pôr a questão referente ao processo de désœuvrement.

Esta "ligeireza" da leitura, que desbanca a figura autoral, que coloca em estado de perda de si as informações exteriores à experiência, que aponta para um estado evanescente do leitor, está associada à potência transgressiva do espaço literário. Esta potência recebeu a denominação de désœuvrement, em L'entretien infini por Blanchot (1969).

Ele demonstra que o désœuvrement seria esta potência transgressiva impessoal que faz a obra literária ser aquilo que é. No entanto, podemos afirmar que o désœuvrement é justamente aquilo que vai fazer a literatura fugir a toda identificação, a toda tradição, a toda amarração sistemática. O désœuvrement é o próprio caráter fugidio da literatura, sua potência de transgressão dos limites da linguagem.

Contudo, estando o désœuvrement do lado desta "afirmação violenta e impessoal", ele não só faz com que as identidades fixas do autor, do escritor e do leitor se percam no turbilhão da experiência, como faz também com que a obra perca sua identidade fechada de obra, para vir a se tornar um livro tão-somente.

Em "L'absence de livre", Blanchot (1969) sublinha que, no espaço literário, existem os processos de désœuvrement e de essencialização da obra. O processo de essencialização da obra visa promovê-la à obra-prima - este conceito fundado no enquadramento das obras literárias nos tesouros culturais - e também designála através da assinatura - processo que consiste na mitologização da figura autoral e no estabelecimento do estilo.

[...] a obra pelo contrário aspira uma singularidade: única, insubstituível, ela é quase um ser; daí, a tendência perigosa da obra se promover em obra-prima, a se essencializar também, isto é, a se designar por uma assinatura (não somente assinada pelo autor, mas, o que seria mais grave, de alguma maneira, assinada por ela-mesma) (BLANCHOT, 1969, p. 623). 
Já o processo de désœuvrement estaria do lado da "ausência de obra", da loucura, do caráter fugidio da literatura, em que as identidades são colocadas em xeque, inclusive a própria identidade de obra, já que a noção de obra acarreta a sua autopromoção ao patamar de obra-prima.

Blanchot, no mesmo texto, afirma que a obra literária "hesita entre o livro, meio de saber e momento evanescente da linguagem e o Livro, elevado à Maiúscula, A Ideia e O Absoluto do livro" (BLANCHOT, 1969, p. 624). Este seria o paradoxo aberto pelo espaço de ressonância e sua relação com a obra literária. Há um embate no seio da leitura: tomar a obra como obra - conceito fechado que toma o livro como elemento único proveniente de um autor e cujo enquadramento histórico o eleva ao grau de conceito - e a obra como livro processo aberto de criação de sentido e de ressonâncias subjetivas. O primeiro estaria ligado ao processo de dialetização da experiência, enquanto o último seria o que ocorre no campo experiencial do ler.

Em um destes diálogos, contidos em L'entretien infini, que estabelece um modo de compreensão em relação a esta "linguagem ao infinito" que é a literatura, Blanchot (1969) marca esta posição contrária do espaço literário em relação aos conceitos de obra-prima e de obra, ou, mais particularmente, a este aspecto fechado e conceitual da ideia de obra, imposto pelos movimentos de unificação do universo cultural.

- A literatura, tal que ela se afirma obscuramente, exclui esta promoção da obra que se chama obra-prima.

- É que ela talvez exclua a ideia de obra também.

- Ao menos, uma certa ideia de obra. Assim, sabemos que conta menos a obra do que a experiência de sua busca e que um artista está sempre prestes a sacrificar a verdade do movimento que aí o conduz (BLANCHOT, 1969, p. 583).

Podemos dizer, ainda, que o leitor, no espaço de ressonância, devido ao processo de désœuvrement, ao ler literatura atravessa a obra tornando-a livro. Diferentemente do que a noção de obra (junto a outros elementos fechados e transcendentes à experiência, como a autoria, o gênero, a obra-prima) faz, o livro seria o espaço realmente aberto, em que os paradoxos da ressonância habitam.

Nietzsche (2001), em um dos aforismos de A gaia ciência, salienta o poder que um livro pode suscitar sobre o corpo de um leitor, quando este entra no espaço ressonante da leitura. Ele pergunta: "De que vale um livro que não nos transporta além dos livros" (NIETZSCHE, 2001, p. 181). "Um livro que transporta para além dos livros": bonita sentença para visualizarmos como a ressonância leitora produz suas mudanças nas esferas subjetiva e de sentido. A obra, quando é transformada em livro pelo processo de acolhimento, leva o leitor para além do universo fechado que a obra representava antes de ser tomada pela leitura. 
Em L'entretien infini, Blanchot (1969) recoloca este problema da seguinte forma: a literatura, devido ao seu caráter fugidio, se apresenta contrária à sua naturalização por parte dos conceitos de obra e de obra-prima, tão importantes para o movimento de unificação cultural e de sistematização da crítica literária. Sendo que a forma manifesta do désœuvrement seria a obra tornada livro, ou seja, a obra desmantelada dos aparatos fechados, impostos por processos dialetizantes da experiência.

A literatura, nós a discernimos, se encontra contrária a toda determinação forte: daí, que ela repugna as obras-primas e mesmo que ela se retira da ideia de obra até fazer desta a forma do désœuvrement (BLANCHOT, 1969, p. 592).

A ideia de obra seria cara à leitura no contexto de seu désœuvrement, ou seja, quando ela é desidentificada do conceito cultural e apresentada como o espaço de experiência - representado pelo livro. Com isso, poderíamos afirmar que a literatura seria uma escrita transgressiva que foge a qualquer ideia de identificação e unificação.

Como expomos neste artigo, o campo experiencial do ler, aberto pelo espaço literário, se caracterizaria como um espaço de ressonância em que forças reativas e ativas colocam em jogo as esferas de sentido e subjetiva. Por isso, podemos assinalar que esse espaço pela literatura proporciona mudanças no campo cognitivo e afetivo. Mostramos ainda que, através da encenação de paradoxos da linguagem, na experiência leitora, há o apagamento do autor, a evanescência do leitor e o desmantelamento da obra. 


\section{Notas}

${ }^{1}$ Em seu estudo sobre o estilo, Noille-Clauzade (2004) afirma que Lanson, em suas análises sobre o objeto literário, instituiu um modo de explicação do texto a partir de um modelo de exegese religioso, que consistia no estabelecimento do entendimento do texto e do estilo do autor.

${ }^{2}$ Em "Sobre algumas funções da literatura", Eco (2003) observa que a permissividade interpretativa leva a uma espécie de heresia crítica, ao sustentar uma posição em que poderíamos ler os textos literários de qualquer forma. Este texto de Eco indica uma das imposturas intelectuais de nosso tempo, em que, parafraseando o Pai Karamázovi, o crítico diz: "Se o Autor morreu, Tudo é Permitido." No entanto, não é bem assim que procede a leitura literária, pois, quando o sujeito atravessa o espaço literário, tanto a intencionalidade do texto quanto seus vividos, sua capacidade intelectual, sua história, suas leituras anteriores, entram no turbilhão da experiência, produzindo o entendimento e, ao mesmo tempo, o surgimento destas características mesmas, antes adormecidas na batalha cotidiana da vida. Um dos paradoxos da leitura literária seria este: não há liberdade da leitura sem intencionalidade do texto, ou ainda, não há intencionalidade do texto sem o exercício da liberdade. No entanto, como Couturier (1995) mesmo assinala, não é Barthes que tem uma atitude permissiva em relação à literatura. Sua preocupação e amor pelo espaço aberto pela linguagem o fez criticar veementemente as posturas críticas de seu tempo, que tendiam a uma valorização excessiva da objetividade e da reverência à intenção do texto. Porém, como Eagleton (1997) indica, Barthes, em S/Z, texto de 1970 em que analisa o Sarrasine de Balzac, defendeu uma apropriação do texto balzaquiano em que tendia a não consumi-lo como um mero leitor, e sim a propagá-lo, produzindo um jogo de escritura sobre o texto. Neste texto barthesiano, a interpretação não é qualquer interpretação. "Barthes tem o cuidado de observar que não se pode fazer com que a obra signifique tudo" (EAGLETON, 1997, p. 189). Na leitura literária, há um jogo livre, lúdico com o texto, mas este jogo não é qualquer um.

${ }^{3}$ Esta análise da experiência literária como experiência da superfície, contrapondo-se às pesquisas da profundidade, usufruídas pelos movimentos interpretacionais, apresenta uma forte semelhança com a oposição, apresentada por Foucault (1966) em La pensée du dehors, entre o pensamento do fora e o pensamento reflexivo, estando o primeiro associado à experiência literária e de superfície, enquanto o segundo à experiência da profundidade e à apreensão interpretativa da obra literária.

${ }^{4}$ Ignorância, acolhimento, ressonância e propagação seriam características imanentes à experiência leitora. Com Blanchot (1987), observamos como o acolhimento leitor se funda na ignorância e na superfície da experiência. O espaço de ressonância se caracterizaria por um espaço de criação, em que elementos externos à experiência não são levados em conta. Quando ignoramos a procedência da obra, o modo como foi criada, o gênero em que se encerra - e outras informações exteriores à obra-, é que nos encontramos mais próximos do que a obra é. Por isso pensamos que o acolhimento e a ignorância na experiência literária, através deste processo ressonante que é a leitura, torna a obra aquilo que é, mediante o processo de entendimento (ALMEIDA, 2009). 


\section{REFERÊNCIAS}

ALMEIDA, L. P. Escrita e leitura: a produção de subjetividade na experiência literária. Curitiba: Juruá, 2009.

BARTHES, R. A morte do autor. In: O Rumor da língua. São Paulo: Brasiliense, 1984. p. 65-70.

BARTHES, R. O prazer do texto. São Paulo: Perspectiva, 2002.

BLANCHOT, M. L'entretien infini. Paris: Gallimard, 1969.

BLANCHOT, M. O espaço literário. Rio de Janeiro: Rocco, 1987.

BLANCHOT, M. A parte do fogo. Rio de Janeiro: Rocco, 1997.

CARROLL, L. Alice no país das Maravilhas. Porto Alegre: LP\&M, 2001.

CARROLL, L. Através do espelho e o que Alice encontrou por lá. In:

Alice: edição comentada - Aventuras de Alice no País das Maravilhas \& Através do Espelho. Rio de Janeiro: J. Zahar, 2002. p. 125-266.

COUTURIER, M. La figure de l'auteur. Paris: Seuil, 1995.

DELEUZE, G. Lógica do sentido. São Paulo: Perspectiva, 2000.

EAGLETON, T. Teoria da literatura: uma introdução. São Paulo: Martins Fontes, 1997.

ECO, U. Sobre algumas funções da literatura. In: Sobre a literatura. Rio de Janeiro: Record, 2003. p. 9-22.

FOUCAULT, M. La pensée du dehors. Revue Critique. Maurice Blanchot. Paris, v. 22, n. 229, p. 533-546, 1966.

FOUCAULT, M. Loucura, literatura, sociedade. In: MOTTA, M. B. da. (Org.). Problematização do sujeito: psicologia, psiquiatria e psicanálise. Rio de Janeiro: Forense Universitária, 1999. Coleção Ditos e Escritos, v. 1, p. 210-234.

FOUCAULT, M. Prefácio à transgressão. In: MOTTA, M. B. da. (Org.). Estética: literatura e pintura, música e cinema. Rio de Janeiro: Forense Universitária, 2001a. Coleção Ditos e Escritos, v. 3, p. 28-46. 
FOUCAULT, M. O Que é um Autor? In: MOTTA, M. B. da. (Org.). Estética: literatura e pintura, música e cinema. Rio de Janeiro: Forense Universitária, 2001b. Coleção Ditos e Escritos, v. 3, p. 264-298.

KUNDERA, M. Les testaments trahis. Paris: Gallimard, 1993.

MAUPASSANT, G. Apparition. In: Paris: Librairie Générale Française, 2000. p. 89-97.

NIETZSCHE, F. A gaia ciência. São Paulo: Companhia das Letras, 2001.

NOILlE-CLAUZADE, C. Le style, textes choisis \& présentés par Christine Noille-Clauzade. Paris: Flammarion, 2004.

PIEGAY-GROS, N. Le lecteur, textes choisis \& présentés par Nathalie PiegayGros. Paris: Flammarion, 2002.

PROUST, M. Contre Sainte-Beuve. Paris: Gallimard, 1954.

SARTRE, J. P. Situations I: essais critiques. Paris: Gallimard, 1947.

Recebido em: 02 de julho de 2014 Aceito em: 03 de setembro de 2014 